Our Nature (2006)4:53-60

\title{
Effect of Seasonal Temperature on Oxygen Consumption in Relation to Body Size of a Fresh-Water Fish, the Flying Barb, Esomus dandricus (Ham.)
}

\author{
H. Bhattacharya and B.R. Subba \\ Department of Zoology, Post Graduate Campus \\ Tribhuvan University, Biratnagar, Nepal
}

Received: 25.09.2006; Accepted: 20.11.2006

\begin{abstract}
Oxygen uptake in relation to body weight was measured in Esomus dandricus at two different seasonal temperatures, winter and summer. Oxygen uptake per unit time $\left(\mathrm{mlO}_{2} / \mathrm{hr}\right)$ increased from 0.5335 to 0.7839 with gradual increase in body weight from 0.5 to $1.5 \mathrm{~g}$ during winter season. During summer, it increased from 0.5539 to 1.4853 with an increase in body weight from 0.6 to $3.3 \mathrm{~g}$. Oxygen uptake per unit time $\left(\mathrm{mlO}_{2} / \mathrm{hr}\right)$ increased by a power of 0.2594 while the oxygen uptake per unit weight $\left(\mathrm{mlO}_{2} / \mathrm{g} / \mathrm{hr}\right)$ decreased by a power of -0.7409 at $16 \pm 1{ }^{\circ} \mathrm{C}$. Oxygen uptake rate per unit time $\left(\mathrm{mlO}_{2} / \mathrm{hr}\right)$ increased by a power of 0.5722 while the oxygen uptake per unit weight $\left(\mathrm{mlO}_{2} / \mathrm{g} / \mathrm{hr}\right)$ decreased by a power of -0.4282 at $25 \pm 1{ }^{\circ} \mathrm{C}$. As the slope of regression line relating to oxygen uptake $(\mathrm{mlO} 2 / \mathrm{hr})$ and body weight in Esomus dandricus is less than 1.0, it can be suggested that the oxygen uptake will decrease with increase in body weight of the fish.
\end{abstract}

Keywords: Flying Barb, Oxygen consumption, Winter, Summer

\section{Introduction}

The oxygen uptake of an organism is considered to be an index for demonstrating the intensity of metabolism. Generally with an increase in metabolic activity the rate of oxygen uptake also increases. Oxygen uptake in a fish depends on various intrinsic and extrinsic factors viz. temperature, photoperiod, $\mathrm{pH}$, salinity, level of dissolved $\mathrm{O}_{2}$ and $\mathrm{CO}_{2}$ in the ambient water, hour of the day, season, nutrition, group size/density, activity level, life cycle stages (larva, juvenile, adult), sex of the fish, body weight etc (Fry, 1957; Prosser, 1973; Dejours, 1975). In fact, oxygen uptake capacity of gills in relation to body weight has been studied in purely aquatic breathing fishes (Kuwar et al. 1989; Roy and Munshi,
1984; Singh et al. 1991; Subba, 2001; Kumari, 2003). Similarly, attempts have also been made to determine the relationship between body weight and metabolic rate of some air-breathing fishes (Munshi et al. 1976, 1978; Biswas et al. 1979).

The Flying Barb, Esomus dandricus, a small fresh water fish belongs to family Cyprinidae. It inhabits in ditches, ponds, pools, canals etc. and is a common fish in Terai of Nepal. The present paper is an attempt to ascertain the effect of seasonal temperature and size on the routine oxygen consumption of the flying barb.

\section{Materials and methods \\ Animals}


Live specimen of flying barbs of different body weights were collected from ditches and canals of Biratnagar and maintained in a cement cistern for a week for acclimatization. Water ( $\mathrm{pH}$ 7) temperature was maintained at $16 \pm 1{ }^{\circ} \mathrm{C}$ during winter and $24 \pm 1{ }^{\circ} \mathrm{C}$ during summer. Fishes were fed daily on phytoplankton and zooplanktons. Before 24 hours of experimentation, a fish of desired size was sorted out and kept in a rectangular aquarium of $76 \times 45 \times 45 \mathrm{~cm}$. The experimented fish was starved for 12 hours before experimentation.

\section{Apparatus}

The oxygen uptake was measured in a cylindrical glass respirometer $(24 \mathrm{~cm}$ long and $7 \mathrm{~cm}$ in diameter) having volume 722 $\mathrm{ml}$. One end of the respirometer was connected to a constant water level reservoir. The outlet of the reservoir was connected to two conical flasks in series to collect the expired water (Figure 1).

\section{Experimental design}

The experimental fish was weighed and introduced into the completely water filled respirometer. The flow of water from reservoir to respirometer was maintained so that the fish did not show any symptom of suffocation or stress. The respirometer was covered with a piece of black cloth to avoid any disturbance to the fish leaving a small window for observation. The fish was allowed to acclimatize for an hour prior to the experiment. Water samples were collected from the conical flasks connected at the beginning (inspired water) and end of the respirometer (expired water).

Concentration of oxygen in the dissolved samples was determined by Winkler's volumetric method (Welch 1948). The oxygen consumption of the fish per unit time $\left(\mathrm{mlO}_{2} / \mathrm{hr}\right)$ and per body weight $\left(\mathrm{mlO}_{2} / \mathrm{kg} / \mathrm{hr}\right)$ was determined by differences in the oxygen levels between ambient water and that supplied to the respirometer along with the rate of water flow and weight of the fish. The oxygen content of the water varied from between 5.86 to $8.5 \mathrm{mg} / \mathrm{l}$ in winter and 5.46 to $7.6 \mathrm{mg} / \mathrm{l}$ in summer.

Regression analysis using logarithmic transformations was done to show the relation between the oxygen uptake rate and body analysis.

\section{Observations}

The measurements of oxygen consumption $\left(\mathrm{VO}_{2}\right)$ for 7 weight groups of fishes and the computed data on the regression analysis showing the relationship between $\mathrm{VO}_{2}$ and body weight have been summarized in Table 1-4 and shown in Figure 1-4.

\section{Relation between oxygen consumption to body weight in during winter $16 \pm 1{ }^{\circ} \mathrm{C}$}

In Esomus dandricus, uptake of oxygen through gills in winter ranged from 0.5335 to $0.7839 \mathrm{ml} / \mathrm{hr}$ within the weight range of 0.5 to $1.5 \mathrm{~g}$ (Table 1 ), when the $\mathrm{O}_{2}$ content ranged from 6.86 to $8.5 \mathrm{mg} / \mathrm{l}$. The relationship between oxygen uptake per unit time $\left(\mathrm{mlO}_{2} / \mathrm{hr}\right)$ and body weight may be represented by the following equation:

$\mathrm{VO}_{2}(\mathrm{ml} / \mathrm{hr})$ Vs. Body weight

$\mathrm{VO}_{2}=\mathrm{aW}^{\mathrm{b}}$

Where, $\mathrm{VO}_{2}=$ oxygen uptake for $1 \mathrm{~g}$ fish

$\mathrm{a}=$ rate of oxygen uptake for $1 \mathrm{~g}$ fish

$\mathrm{W}=$ body weight

$\mathrm{b}=$ slope of regression coefficient

The log-log plot of the oxygen uptake $\left(\mathrm{mlO}_{2} / \mathrm{hr}\right)$ in relation to the body weight gave a straight line with a slope of 0.2595 and the estimated value for a $1 \mathrm{gm}$ fish was 
H. Bhattacharya and B.R.Subba / Our Nature (2006)4:53-60

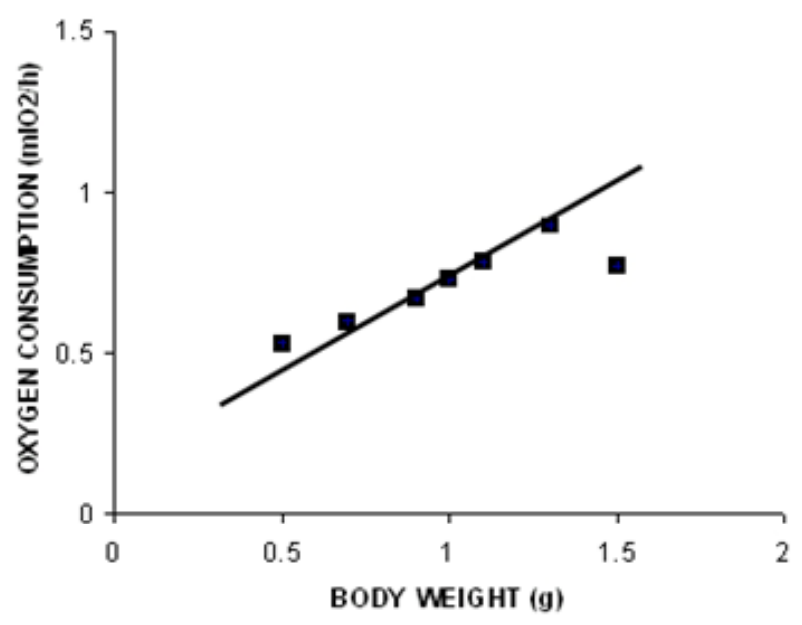

miO2/hr

Figure 1. Log/log plots showing the relationship between oxygen uptake and body weight $\left(\mathrm{mlO}_{2} / \mathrm{hr}\right)$ at $16 \pm 1{ }^{\circ} \mathrm{C}$ temperature in Esomus dandricus.

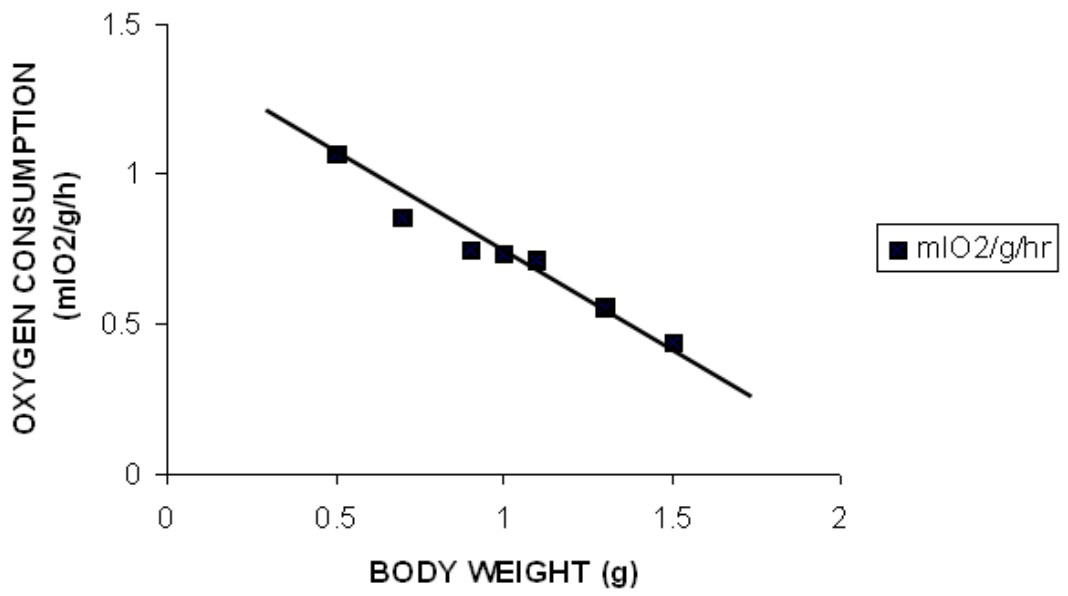

Figure 2. $\mathrm{Log} / \log$ plots showing the relationship between body weight and weight specific oxygen consumption $(\mathrm{mlO} / \mathrm{g} / \mathrm{hr})$ at $16 \pm 1{ }^{\circ} \mathrm{C}$ temperature in Esomus dandricus. 


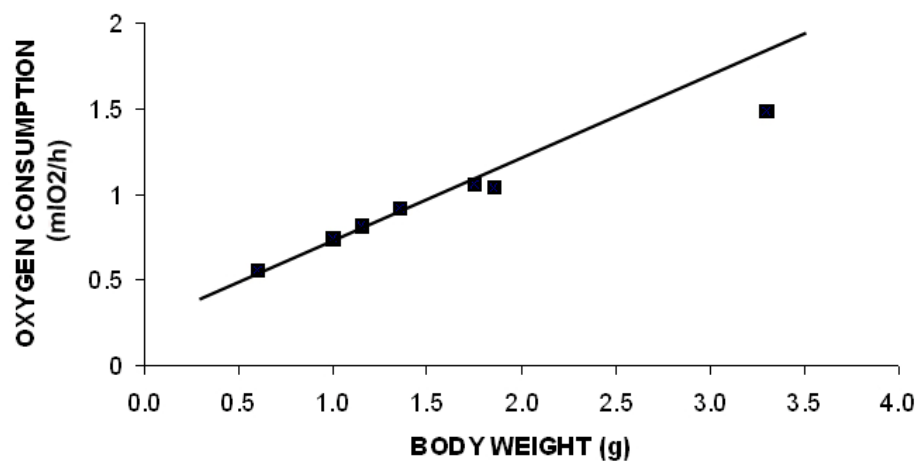

- $\mathrm{mlO} 2 \mathrm{hr}$

Figure 3. $\log / \log$ plots showing the relationship between oxygen uptake and body weight $\left(\mathrm{mlO}_{2} / \mathrm{hr}\right)$ at $25 \pm 1{ }^{\circ} \mathrm{C}$ temperature in Esomus dandricus.

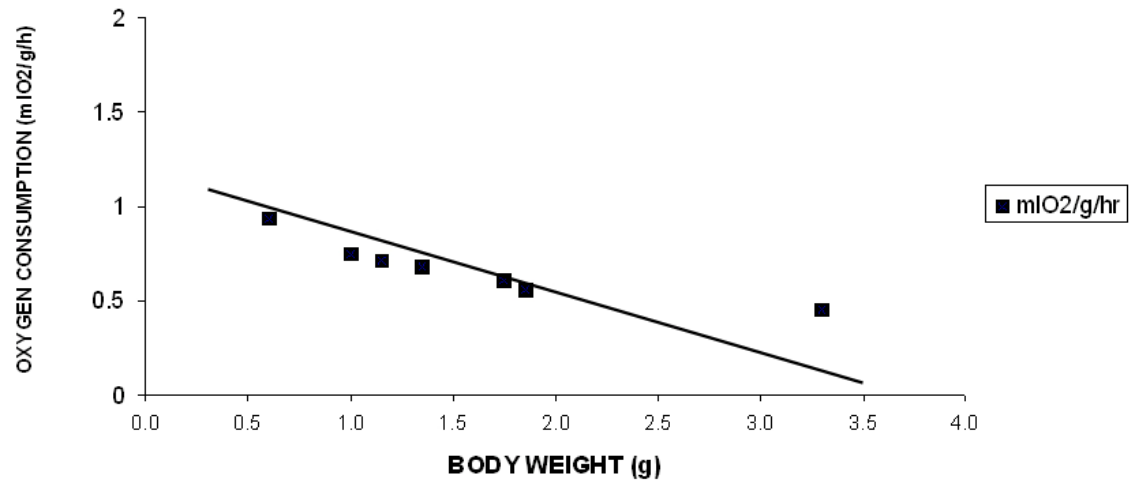

Figure 4. $\log / \log$ plots showing the relationship between body weight and weight specific oxygen consumption $\left(\mathrm{mlO}_{2} / \mathrm{g} / \mathrm{hr}\right)$ at $25 \pm 1^{\circ} \mathrm{C}$ temperature in Esomus dandricus. 
H. Bhattacharya and B.R.Subba / Our Nature (2006)4:53-60

Table 1. Oxygen uptake in relation to body weight in winter

\begin{tabular}{|c|c|c|c|c|c|c|c|}
\hline \multirow{2}{*}{$\begin{array}{l}\text { Body } \\
\text { weight }\end{array}$} & \multirow{2}{*}{$\begin{array}{l}\text { Atm. } \\
\text { Temp. }{ }^{\circ} \mathrm{C}\end{array}$} & \multirow{2}{*}{$\begin{array}{l}\text { Ambient } \\
\text { Temp. }{ }^{\circ} \mathrm{C}\end{array}$} & \multirow{2}{*}{$\begin{array}{l}\text { Opercular } \\
\text { frequency } \\
\text { (min) }\end{array}$} & \multicolumn{3}{|c|}{ Oxygen Uptake } & \multirow{2}{*}{$\begin{array}{l}\text { Estimated } \\
\text { value }\end{array}$} \\
\hline & & & & $\mathrm{mlO}_{2} / \mathrm{hr}$ & $\mathrm{mlO}_{2} / \mathrm{g} / \mathrm{hr}$ & $\mathrm{mlO}_{2} / \mathrm{kg} / \mathrm{hr}$ & \\
\hline 0.5 & 15 & 16 & 76 & 0.5335 & 1.0670 & 1067.04 & 0.5646 \\
\hline 0.7 & 15 & 15.5 & 74 & 0.5995 & 0.8562 & 856.21 & 0.6157 \\
\hline 0.9 & 16 & 16 & 74 & 0.6713 & 0.7458 & 745.85 & 0.6568 \\
\hline 1.0 & 16 & 17 & 72 & 0.7296 & 0.7296 & 729.61 & 0.6749 \\
\hline 1.1 & 15 & 17 & 70 & 0.7839 & 0.7127 & 712.72 & 0.6917 \\
\hline 1.3 & 15 & 17 & 70 & 0.7187 & 0.5523 & 552.28 & 0.7221 \\
\hline 1.5 & 16 & 16 & 68 & 0.6533 & 0.4355 & 435.55 & 0.7492 \\
\hline $\mathrm{Avg}=1.00$ & Avg $=15.43$ & Avg $=16.36$ & Avg $=72$ & $A v g=0.6699$ & $A v g=0.7284$ & $A v g=728.46$ & Avg $=0.6678$ \\
\hline
\end{tabular}

Table 2. Summary of oxygen uptake showing intercept (a), slobe (b) and correlation coefficient (r) in winter

\begin{tabular}{llll}
\hline $\begin{array}{l}\text { Body wt (w) vs. } \mathbf{O}_{2} \\
\text { consumption }\end{array}$ & Intercept (a) & Slobe (b) & $\begin{array}{l}\text { Correlation coefficient } \\
\text { (r) }\end{array}$ \\
\hline $\mathrm{VO}_{2}\left(\mathrm{mlO}_{2} / \mathrm{h}\right)$ & 0.6749 & 0.2595 & 0.7464 \\
$\mathrm{VO}_{2}\left(\mathrm{mlO}_{2} / \mathrm{g} / \mathrm{h}\right)$ & 0.6760 & -0.7409 & -0.9542 \\
\hline
\end{tabular}

Table 3. Oxygen uptake in relation to body weight in summer

\begin{tabular}{|c|c|c|c|c|c|c|c|}
\hline \multirow{2}{*}{$\begin{array}{l}\text { Body wt. } \\
\text { (g) }\end{array}$} & \multirow{2}{*}{$\begin{array}{l}\text { Atm. } \\
\text { Temp }{ }^{0} \mathrm{C}\end{array}$} & \multirow{2}{*}{$\begin{array}{l}\text { Ambient } \\
\text { Temp }\end{array}$} & \multirow{2}{*}{$\begin{array}{l}\text { Opercular } \\
\text { frequency } \\
\text { (min) }\end{array}$} & \multicolumn{3}{|c|}{ Oxygen uptake } & \multirow{2}{*}{$\begin{array}{l}\text { Estimated } \\
\text { value }\end{array}$} \\
\hline & & & & $\mathrm{mlO}_{2} / \mathrm{hr}$ & $\mathrm{mlO}_{2} / \mathrm{g} / \mathrm{hr}$ & $\mathrm{mlO}_{2} / \mathrm{kg} / \mathrm{hr}$ & \\
\hline 0.6 & 27 & 26 & 96 & 0.5539 & 0.9307 & 930.66 & 0.5632 \\
\hline 1.0 & 25 & 24.5 & 96 & 0.7467 & 0.7467 & 746.66 & 0.7544 \\
\hline 1.15 & 25.5 & 24 & 95 & 0.8227 & 0.7154 & 715.39 & 0.8172 \\
\hline 1.35 & 26 & 25 & 93 & 0.9195 & 0.6811 & 681.11 & 0.8958 \\
\hline 1.75 & 26 & 25 & 92 & 1.0647 & 0.6084 & 608.39 & 1.0392 \\
\hline 1.85 & 26 & 25.5 & 90 & 1.0386 & 0.5614 & 561.42 & 1.0727 \\
\hline 3.3 & 25 & 22 & 82 & 1.4853 & 0.4501 & 450.10 & 1.4939 \\
\hline $\mathrm{Avg}=1.57$ & $\mathrm{Avg}=25.78$ & Avg $=24.57$ & Avg $=92$ & Avg $=0.9479$ & Avg $=0.6705$ & $\mathrm{Avg}=670.53$ & Avg $=0.9481$ \\
\hline
\end{tabular}

Table 4. Summary of oxygen uptake showing intercept (a), slobe (b) and correlation coefficient (r) in summer

\begin{tabular}{llll}
\hline $\begin{array}{l}\text { Body wt (w) vs. } \mathbf{O}_{2} \\
\text { consumption }\end{array}$ & Intercept (a) & Slobe (b) & $\begin{array}{l}\text { Correlation coefficient } \\
\text { (r) }\end{array}$ \\
\hline $\mathrm{VO}_{2}\left(\mathrm{mlO}_{2} / \mathrm{h}\right)$ & 0.7544 & 0.5722 & 0.9977 \\
$\mathrm{VO}_{2}\left(\mathrm{mlO}_{2} / \mathrm{g} / \mathrm{h}\right)$ & 0.7545 & -0.4282 & -0.3536 \\
\hline
\end{tabular}


found to be $0.6749(\mathrm{ml} / \mathrm{hr}$, Table 2). Therefore, substituting the values:

$\mathrm{VO}_{2}=0.6749 . \mathrm{W}^{0.2595}$

Or, $\log \mathrm{VO}_{2}=\log -0.1707+0.2595 . \log \mathrm{W}$

The correlation coefficient ' $r$ ' between oxygen uptake and body weight was 0.7464 ( $>0.02$ ). The estimated values for 1,10 and $20 \mathrm{~g}$ fish were $0.6749,1.2209$ and 1.4594 respectively during winter.

The log-log plot of the oxygen uptake $\left(\mathrm{mlO}_{2} / \mathrm{g} / \mathrm{hr}\right)$ in relation to the body weight gave a slope of -0.7409 (Figure 2) and the estimated value for a $1 \mathrm{gm}$ fish was found to be $0.6760 \quad(\mathrm{ml} / \mathrm{g} / \mathrm{hr})$. The relationship between the body weight and weight specific oxygen uptake rate has been shown by the following equation:

$\mathrm{VO}_{2}=0.6760 . \mathrm{W}^{-0.7409}$

Or, $\log \mathrm{VO}_{2}=-0.1700-0.7409$

The weight specific oxygen uptake rate decreased with unit increase in body weight by a power of -0.7409 . The correlation coefficient ( $\mathrm{r}$ ) was found to be -0.9542 . The estimated value of oxygen uptake rate $\left(\mathrm{mlO}_{2} / \mathrm{g} / \mathrm{h}\right)$ for 1,10 and $20 \mathrm{~g}$ fish were $0.6760,0.1228$ and 0.0735 respectively.

\section{Relation between oxygen consumption to} body weight in during summer $25 \pm 1{ }^{\circ} \mathrm{C}$

In Esomus dandricus, uptake of oxygen through gills in summer ranged from 0.5539 to $1.4853 \mathrm{ml} / \mathrm{hr}$ within the weight range of 0.6 to $3.3 \mathrm{~g}$ (Table 3 ). Under this condition the dissolved oxygen went down to 5.46 $7.6 \mathrm{mg} / \mathrm{l}$. The relationship between oxygen uptake per unit time $\left(\mathrm{mlO}_{2} / \mathrm{hr}\right)$ and body weight may be represented by the following equation:

$\mathrm{VO}_{2}(\mathrm{ml} / \mathrm{hr})$ Vs. Body Weight

The log-log plot of the oxygen uptake $\left(\mathrm{mlO}_{2} / \mathrm{hr}\right)$ in relation to the body weight gave a a slope of 0.5722 and the estimated value for a $1 \mathrm{gm}$ fish was found to be $0.7544(\mathrm{ml} / \mathrm{hr})$

(Table 4). Therefore, substituting the values: $\mathrm{VO}_{2}=0.7544 . \mathrm{W}^{0.5722}$

Or, $\log \mathrm{VO}_{2}=\log -0.1224+0.5722 . \log \mathrm{W}$

The correlation coefficient ' $r$ ' between oxygen uptake and body weight was 0.9977 ( $>0.001)$. The estimated values for 1,10 and $20 \mathrm{~g}$ fish were $0.7544,2.8172$ and 4.1886 respectively during summer.

The log-log plot of the oxygen uptake $\left(\mathrm{mlO}_{2} / \mathrm{g} / \mathrm{hr}\right)$ in relation to the body weight gave a slope of -0.4282 (Figure 4) and the estimated value for a $1 \mathrm{gm}$ fish was found to be $0.7545 \quad(\mathrm{ml} / \mathrm{g} / \mathrm{hr})$. The relationship between the body weight and weight specific oxygen uptake rate has been shown by the following equation:

$\mathrm{VO}_{2}=0.7545$. W $\mathrm{W}^{-0.4282}$

Or, $\log \mathrm{VO}_{2}=-0.1223-0.4282 . \log \mathrm{W}$

The weight specific oxygen uptake rate decreased with unit increase in body weight by a power of -0.4282 . The correlation coefficient ( $r$ ) was found to be -0.3536 . The estimated value of oxygen uptake rate $\left(\mathrm{mlO}_{2} / \mathrm{g} / \mathrm{h}\right)$ for 1,10 and $20 \mathrm{~g}$ fish were $0.7545,0.2815$ and 0.2092 respectively.

\section{Discussion}

The rate of oxygen uptake in a fish depends upon various abiotic and biotic factors (Imabayashi and Takahashi, 1987). Of the biotic factors, body weight plays a very important role and it is well known that normal increase in oxygen uptake is associated with an increase in weight. Since the value of exponent ' $b$ ' relating to oxygen uptake per until time in most fishes is less than 1 , the weight specific oxygen uptake $\left(\mathrm{mlO}_{2} / \mathrm{g} / \mathrm{hr}\right)$ decreased with an increase in body weight.

Several workers have suggested different exponent values to state the relationship 


\section{H. Bhattacharya and B.R.Subba / Our Nature (2006)4:53-60}

between oxygen uptake and body weight (Brody, 1945; Zeuthen, 1947; Brett, 1972; Kamler, 1976). Scholander et al. (1953) gave 0.85 as the most general value for fish. Winberg (1957) estimated the average slope value of 0.81 for a number of fish species. Paloheimo and Dickie (1965) suggested 0.80 to be a characteristic exponent value for most teleost species. Prosser and Brown (1961) generalized this value and suggested that this could range from 0.67 to 1.0 . However, exception to this range is not uncommon. Exponent value as low as 0.5 was reported by Ruhland (1965) and 0.531 by Munshi and Dube (1973). Similarly, exponent values of more than 1.0 means that they predict the weight specific oxygen uptake increases with increasing body weight.

In the present study, oxygen uptake per unit time in the fresh water fish, Esomus dandricus was found to increase with body weight and the exponent value relating to oxygen uptake and body weight was estimated to be 0.259 in winter and 0.572 during summer. Ojha et al. (1977) found it to be 0.595 for Colisa fasciatus, Munshi and Dube (1973) found the value to be 0.531 for Anabas testudineus. The exponent value of Esomus dandricus in summer fits in the foresaid range of regression coefficient but lower than the value of most hill-stream and aquatic breathing fishes. Lower exponent value in Esomus dandricus (0.259 in winter and 0.572 in summer) indicates a lesser increase in oxygen uptake rate per unit time with unit increase in body weight in comparison to most of the aquatic and hillstream fishes.

In most of the fishes the exponent value relating to $\mathrm{VO}_{2}\left(\mathrm{mlO}_{2} / \mathrm{hr}\right)$ and body weight is less than 1 , and therefore the oxygen uptake per unit body weight $\left(\mathrm{mlO}_{2} / \mathrm{g} / \mathrm{hr}\right)$ will decrease with increase in body weight. This finding corroborates the earlier view of Prigogine and Wiame (1946) that for the thermodynamic reasons, the metabolic rate can never increase but decrease with evolution of body size in organisms. Lower metabolic rate in higher weight groups of fishes maybe due to the fact that the sum of enzymes, metabolites and perhaps inhibitors, which govern various metabolic activities of organism, is lower in comparison to growing tissue. This statement holds good for Esomus dandricus where oxygen uptake per unit body weight $\left(\mathrm{mlO}_{2} / \mathrm{g} / \mathrm{hr}\right)$ decreases by a power of -0.7409 in winters and -0.4282 in summers.

Esomus dandricus of $1 \mathrm{~g}$ body weight showed higher oxygen uptake rate per unit time $\left(0.675 \mathrm{mlO}_{2} / \mathrm{hr}\right)$ in winter and $(0.754$ $\mathrm{mlO}_{2} / \mathrm{hr}$ ) in summer. Oxygen uptake rate per unit time $\left(\mathrm{mlO}_{2} / \mathrm{hr}\right)$ for $1 \mathrm{~g}$ fish is greater than the values of most purely aquatic breathing and air-breathing fishes, Ancipencer stellatus (0.577), Anguilla anguilla (0.277), Cyprinus carpio (0.186), Salmo gairdneri (0.369), Salmo trutta (0.358), Tinca tinca (0.329) and airbreathing fishes like Anabas testudineus (0.545), Clarias batrachus (0.134) but lower than the value obtained for Colisa fasciatus (0.894). Oxygen uptake per unit time for $1 \mathrm{~g}$ of $E$. dandricus was greater than hill-stream fishes like Noemacheilus rupicola $\left(0.676 \mathrm{mlO}_{2} / \mathrm{g} / \mathrm{hr}\right)$ in winter and (0.754 $\left.\mathrm{mlO}_{2} / \mathrm{g} / \mathrm{hr}\right)$ in summer. Higher oxygen uptake in Esomus dandricus shows better development of gills in this fish.

The fish being surface feeder, remains on the surface of the water most of the time and extracts oxygen from the atmosphere. It may be one of the reasons that the exponent value of oxygen uptake in Esomus dandricus is lesser than other fishes. 


\section{H. Bhattacharya and B.R.Subba / Our Nature (2006)4:53-60}

\section{References}

Biswas, N., J. Ojha and J.S.D. Munshi 1979. Bimodal oxygen uptake in relation to body weight of the amphibious mudskipper, Boleophthalmus boddaerti (Pall). Ind. J. Exp. Biol. 17: 752-756.

Brett, J.R. 1972. The metabolic demand for oxygen in fish, particularly salmonids and comparison with other vertebrates. Respir. Physiol. 14:151-170.

Brody, S. 1945. Bioenergetics and growth, with special reference to the efficiency complex in domestic animals, Reinhold, New york, pp. 1023.

Dejours, P. 1975. Principles of comparative respiratory physiology, American Elsevier, Amsterdam, New York, North Holland, 252p.

Fry, F.E.J. 1957. The aquatic respiration in fish. In The Physiology of Fishes, (Ed. M.E. Brown), Vol. 1.Academic Press, New York, pp. 1-63.

Imabayashi, H. and M. Takahashi 1987. Oxygen consumption of post larval and juvenile Red Sea Bream, Pagrus major with special reference to group effect. J. Fac. Appl. Biol. Sci. 26: 15-21.

Kamler, E. 1976. Variability of respiration and body composition during early developmental stages of carp. Pol. Arch. Hydrobiol. 23 (3): 431-485.

Kumari,R.(2003).General organization and scaling pattern of therespiratory organ inrelation body weight in a freshwater featherback Notopterus chitala (Ham.) T.M Bhagalpur University Bhagalpur.India. ( $\mathrm{Ph} \mathrm{D}$ thesis)

Kunwar, G.K., A. Pandey and J.S.D. Munshi 1989. Oxygen uptake in relation to body weight of two fresh water major carps Catla catla (Ham.) and Labeo rohita (Ham.). Indian. J. Anim. Sci. 59(5): 621-624.

Munshi, J.S.D and S.C. Dube 1973. Oxygen uptake capacity of gills in relation to body size of the airbreathing fish, Anabas testudineus (BI.). Acta. Physiol. Hung. 44: 113-123.

Munshi, J.S.D., B.N. Pandey., P.K. Pandey and J. Ojha 1978. Oxygen uptake through gills and skin in relation to body weight of an air-breathing siluroid fish Saccobrabchus (=Heteropneustes) fossilis. J. Zool. Lond. 184: 171-180.

Ojha, J., O.P. Dandotia and J.S.D. Munshi 1977. Oxygen consumption of an amphibious fish
Colisa fasciatus in relation to body weight. Pol. Arch. Hydrobiol. 24: 547-553.

Paloheimo, J.F. and L.M. Dickie. 1965. Food and growth of fishes I.A. growth curve derived from experimental data. J. Fish. Res. BD. Can. 22: 521542.

Prigogine, J. and J.M. Wiame. 1946. Biologie at thermodynamique des phenomenas irreversibles. Experimentia, (Basal). 2: 451-453.

Prosser, C.L. 1973. Comparative Animal Physiology. W.B. Saunder Co. Philadelphia and London, pp.456.

Prosser, C.L. and F.A. Brown (Tr.) 1961. Respiratory function of body fluids. In: Comparative Animal Physiology (Ed. II) W.B. Saunder Co. Philadelphia and London.

Roy, P.K. and J.S.D. Munshi 1984. Oxygen uptake in relation to body weight and respiratory surface in Cirrhinus mrigala (Ham.) at two different seasonal temperatures. Proc. Indian Nath. Sci. Acad. B50: 387-394.

Ruhland, M.L. 1965. Etude comparative de la consummation d' chez differentes especes de poisons teleosteans. Bull. Soc. Zool. France. 90: 347-353.

Scholander, P.F., W. Flagg., V. Walters and L.Irving 1953. Climatic adaptation in artic and tropical poikilotherms. Physiol. Zool. 26: 67-82.

Singh, D.K., O.N. Munshi and J.S.D. Munshi 1991. Oxygen uptake in relation to body weight in Rita rita (Ham.) (Bagridae, Pisces) at two different seasonal temperatures. J. Freshwater Biol. 3(1): 15-21.

Subba B.R. 2001. Structure and function of the respiratory organ of a hillstream fish Glyptothorax telchitta(Ham.) from Nepal. T.M. Bhagalpur University,s Bhagalpur, India. (Ph D thesis)

Winberg, G.G. 1956. Rate of metabolism and food requirement of fishes (Nauchnye Trudy Belorusskogo Gosud arvennogy Universiteta imeniv.) I. Lemina, Minsk. Fish. REs. Bd. Vand. Trans. Ser. No. 194.

Zeüthen. E. 1947. Body size and metabolic rate in the animal kingdom with special regard to the marine microfauna. C.r. Lab. Carlsberg. Ser. Chim. 28: $1-12$. 